\title{
4. Sınıf İngilizce Dersi Öğretim Programının Bağlam, Girdi, Süreç, Ürün Modeline Göre Değerlendirilmesi
}

\author{
Abdulkadir KURT ${ }^{1}$ \\ 1 Arș.Gör., Akdeniz Üniversitesi, Eğitim Fakültesi, Eğitim Bilimleri ABD, abdulkadirkur@a,adeniz.edu.tr
}

Geliş Tarihi/Received: 29.11.2016 Kabul Tarihi/Accepted: 6.4.2017 e-Yayım/e-Printed: 4.7.2017

DOI: http://dx.doi.org/10.14582/DUZGEF.1801

ÖZ

Bu araștırmanın amacı 2012-2013 eğitim-öğretim yll 4+4+4 kademeli ve zorunlu eğitim sistemi ile birlikte uygulamaya konulan 4. sınıf İngilizce dersi öğretim programını Stufflebeam’in Bağlam-Girdi-Süreç-Ürün (BGSÜ) modelini kullanarak kapsamlı bir şekilde değerlendirmektir. Dinleme ve konuşma becerilerine yönelik kazanımların ağırlıklı olduğu 4. Sinıf İngilizce dersi öğretim programı bu beceriler bağlamında 4. Ünite (Cartoon Characters) ve 5. Ünite (My Day) ile sinırlandırılarak değerlendirilmiștir. Bu amaç doğrultusunda çalıșmada karma araștırma yöntemi kullanılmıştır. Araştırmanın çalıșma grubunu Antalya ili merkez ilçelerine ait 2015-2016 TEOG İngilizce dersi sınav başarı ortalamaları sonucunda orta seviyede yer aldığı belirlenen ve amaçlı örnekleme yöntemi ile tercih edilen bir devlet İlkokulunun 4. sınıf öğrencileri, bu sınıfin İngilizce öğretmeni, okul yöneticisi ile program geliștirme uzmanı ve ders kitabı yazarı olusturmaktadır. Araștırmada veri toplama aracı olarak gözlem, yarı yapılandırılmıs görüsme formları ve başarı testleri kullanılarak veri çeşitlemesi sağlanmıştır. Araştırmadan elde edilen nitel veriler ilgili sınıfın 10 hafta boyunca gözlenmesi; İngilizce öğretmeni, okul yöneticisi, program geliştirme uzmanı ve ders kitabı yazarı ile yapılan görüşmeler ve ögretim programı ile ders kitabının analizi sonucunda elde edilmiștir. Çalıșmadan elde edilen nicel veriler ise ilgili sınıfa araștırmacı tarafından uygulanan bașarı testlerinin analizi sonucunda elde edilmiștir. Nitel verilerin analizinde içerik analizi yöntemi kullanılırken başarı testlerinden elde edilen nicel verilerin analizinde ise Wilcoxon İşaretli Sıralar Testi kullanılmıştır. Elde edilen nitel ve nicel veriler ilk aşamada ayrı ayrı incelenmiş olup daha sonra programın geneli hakkında bir yargıda bulunabilmek için Stufflebeam'in BGSÜ modeli kapsamında değerlendirilmiștir. Araștırma sonuçlarına bakıldığında programın öğrenci ihtiyaçları temel alınarak hazırlandığ1 ancak okulun bulunduğu bölgenin sahip olduğu farklı şartların dikkate alınmayarak programın hazırlandığ1 tespit edilmiştir. Okulun sahip olduğu bütçe ve teknik donanımın yetersiz olduğu ve dolayısılla dinleme ve konuşma becerilerine yönelik alt yapının arzu edilen seviyede olmadığı sonucuna varılmıștır. Öğrenme-öğretme süreci bağlamında zaman kısıtllı̆ı̆ı, dinleme ve konuşma becerilerinin ögretimine ilișkin tercih edilen yöntem ve teknikler, materyal yetersizliği ve öğretmen-öğrenci iletișimsizliği gibi problemler yaşandığ1 görülmüştür. Program uygulandıktan sonra öğrencilerin dinleme ve konuşma becerilerinde olumlu yönde bir artış olduğu ancak bu artışın istenilen seviyede olmadığı sonucuna varılmıştır.

Anahtar Kelimeler: Program değerlendirme, BGSÜ program değerlendirme modeli, 4. sınıf İngilizce dersi öğretim programı

\section{The Evaluation of $4^{\text {th }}$ Grade English Language Curriculum By Context, Input, Process, Product Model}

\begin{abstract}
The purpose of this research is to evaluate inclusively $4^{\text {th }}$ grade English Language curriculum implemented with $4+4+4$ gradual and compulsory educational system in 2012-2013 academic year by using Context-Input- Process-Product (CIPP) model of Stufflebeam. 4th grade English Language curriculum in which the gains of listening and speaking skills emphasized was evaluated in terms of these skills by confining with $4^{\text {th }}$ unit (Cartoon Characters) and $5^{\text {th }}$ unit (My Day). Mixed research method was used in line with this purpose in this research. The study group of this research is consisted of curriculum development expert, book author with $4^{\text {th }}$ grade students, English teacher and the principal of public primary school which was determined as a medium level school and preferred with purposive sampling as a result of the exam of transition from primary to secondary education belonging to central districts of Antalya province. Triangulation was ensured by using different data collection tools as observation, semi-structured interview form and achievement tests. Qualitative data of the research was obtained by the observation of the class along 10 weeks; interview with English teacher, school principal, curriculum development expert and book author and also analysis results of curriculum and course book. Quantitative data of the research was obtained as a result of the analysis of achievement tests implemented by the researcher. While content analysis was used for qualitative data, Wilcoxon Signed Rank Test was used for quantitative data obtained from achievement tests. In the first phase both qualitative and quantitative data was analysed separately and then in the second phase, they were evaluated within Stufflebeam's CIPP model to make judgement on overall design of curriculum. When the results analyzed, it was found out that curriculum was prepared based on students' need but without taking into consideration different conditions of schools in both urban and rural districts. The budget and technical equipment of school was found insufficient to meet needs so it was concluded that substructure towards listening and speaking skills were not in a desired level. When the results related to process evaluation analyzed, some issues were seen such as time limitation, methods and techniques for listening and speaking skills, lack of supplies, non-communication between teacher and students. Positive increase was seen on listening and speaking skills of students, but this increase was not occurred in a desired level.
\end{abstract}

Keywords: Curriculum evaluation, CIPP curriculum evaluation model, $4^{\text {th }}$ grade English Language Curriculum 


\section{GİRİŞ}

Yaşayan binlerce dil arasında gösterilen ve farklı kıtalarda en çok kullanılan dil olma özelliğinin yanı sıra gelişmiş ülkelerin sürekli gelişen teknolojisi ve dünyanın bilim alanında yapılmış olan çalışmalarının yarısının İngilizce yazılmış olmas1, 21.yüzyılda bilgiye ulaşabilme noktasında İngilizceyi en önemli iletişim dili haline getirmiştir (Broughton, Brumfit, Flavell, Hill ve Pincas, 2003). Teknolojik gelişmelerin üst düzeyde yaşandığ1 gelişmiş ülkelerin resmi dillerinin İngilizce olması ve bu teknolojiyle ortaya konulan bilimsel faaliyetler, film, sinema, müzik ve internete ulaşmanın yanı sıra bu ülkelerle olan politik, ekonomik, kültürel ilişkilerin gerçekleşebilmesi için İngilizce küresel bir dil olma özelliğine bürünmüştür (Crystal, 2003). Buradan hareketle İngilizcenin bilim, teknoloji, eğitim, politika, ekonomi gibi alanlarda uluslararası ilişkilerin sürdürülebilir olmasında büyük bir rol oynadığı söylenebilir. Yaşanılan bu gelişmeler Türkiye’nin de yabancı dil eğitim politikalarını etkilemiş ve 1997 yılında İngilizcenin İlkokul 4. sınıftan itibaren yabancı dil olarak öğretimi zorunlu kilınmıştır.

Yabancı bir dili öğrenmek, öğrenenler için genellikle zaman alıcı ve sabır gerektiren yoğun bir süreçtir (Sarıçoban ve Hasdemir, 2012). Bundan dolayı, çok sayıda gelişmiş ülkede yabancı dil öğretimine erken yaşlardan itibaren başlanmaktadır (MEB A.P.K. Kurulu Başkanlığı, 1999). Yabancı bir dilin öğrenilmesi üzerine yapılan bazı araştırmalar da erken yaşlarda öğrenilmeye başlanılan anadilin yanı sıra eş zamanlı öğrenilen yabancı bir dilin bilişsel ve kavramsal açıdan hem daha kolay öğrenildiğini hem de daha kalıcı olduğunu ortaya koymuştur (Haznedar, 2003; Karakoç, 2007). Demirezen (2003) de erken yaşta yabanc1 dil ediniminin, öğrencilere daha kolay ve akılda daha kalıcı bir yabancı dil öğrenme zemini hazırlayacağını; yabancı dili ve dilleri daha kolay konuşan öğrencilerin yetişmesine olanak sağlayacağını ifade etmiştir. Birçok Avrupa ülkesinde de İngilizcenin ilkokuldan başlayarak zorunlu yabancı dil öğretimi olarak programlara dahil edilmesi ve bu durumun dünya çapında bir olgu haline gelmesi, İngilizcenin erken yaşlarda öğretimini son yıllarda önemli hale getirmiştir (Scott ve Ytreberg, 2008).

Türkiye'de de erken yaşta yabancı dil öğretimi 1998’e kadar özel okullarla sınırlıyken 1997-1998 eğitim öğretim döneminde zorunlu eğitimin 8 yıla çıkarılmasıyla birlikte tüm devlet okullarında ilköğretimin 4 . sınıflarından başlamak kaydıyla haftada 2 saat zorunlu, 1 saat seçmeli ders olarak sürece dahil edilmiştir. (Aslan, 2008). 2006-2007 eğitim-öğretim y1lından itibaren güncellenen müfredatla birlikte haftada 3 saat zorunlu İngilizce dersi ve 2 saat seçmeli İngilizce, Fransızca ve Almanca dersleri verilmeye başlanmıştır (Çetintaş, 2010; Egel, 2009). 2012-2013 öğretim yllındaki 4+4+4 kademeli ve zorunlu eğitim reformu ile birlikte zorunlu İngilizce dersi ilkokul 2., 3. ve 4. sınıflarda haftada 2 saat olarak uygulanmaya başlanmıştır. Dolayısıyla ülkemizde bu alanda yapılan reform ve uyum çalışmalarına bakıldığında bu çalışmaların, çocukların erken yaşta yabancı bir dili edinmelerine imkân tanıyan bir öğrenme ortamı oluşturma çabasıyla eğitim-öğretim sürecine dâhil edildiği söylenebilir. Üç kademeden oluşan 4+4+4 kademeli ve zorunlu eğitim reformu ile yabancı dil öğretim programı ilk defa 2013-2014 eğitim-öğretim yllında 2. sınıflarda uygulanmaya başlanmıştır. Birinci kademede dinleme ve konuşma becerilerine ağırlık verilerek oluşturulan kazanımların öğrencilerdeki yansımalarını ortaya koymak için birinci kademenin son sınıfı olan ve ilkokuldan ortaokula geçişte de bir köprü niteliği taşıdığı için 2015-2016 eğitim öğretim yllında programın uygulandığı ilkokul 4. sınıf bu çalışmada İngilizce dersi öğretim programının değerlendirilmesi için tercih edilmiştir. İlkokul 4. sınıf öğretim programı dört temel dil becerilerinden (okuma, yazma, konuşma ve dinleme) ağırlıklı olarak dinleme ve konuşma becerilerine odaklı ve etkin dil kullanımına dayalı bir biçimde tasarlanarak hedef yaş grubunun ilgi ve becerilerine uygun aktiviteler ile desenlenmiştir. Hedeflenen kazanımları edindirmek için özellikle dinleme ve konuşma becerisi üzerine etkinlikler tasarlanmıstır (MEB, 2013).

Yabancı dil alanında yapılan program geliştirme çalışmalarına bakıldığında Türkiye'de Cumhuriyetten günümüze kadar düzenli olarak program geliştirme çalışmalarına yer verildiği ve çok sık program değişikliğine gidildiği görülmektedir (Yüksel, 2003). Ancak geliştirilen ve uygulanan programların sonuçları yeterince değerlendirilememektedir. Bu alanda sayıca yetersiz olmakla beraber yapılan programların ne derece etkili 
olduğunu ve uygulandığını ortaya koyan program değerlendirme çalışmalarına bakıldığında değerlendirmelerin genellikle öğretmen ve öğrenci görüşleri doğrultusunda yapıldığı görülmektedir (Kurt ve Erdoğan, 2015).

Bu çalışma Stufflebeam’in programın tüm öğelerine yönelik ayrıntılı bir şekilde değerlendirme imkanı sunan Context-Input-Process-Product (CIPP), diğer bir değişle Bağlam-Girdi-Süreç-Ürün (BGSÜ) modeli kullanılarak İlkokul 4. sınıf İngilizce dersi öğretim programının uygulamadaki etkililiği, öğretmen ve öğrenci rolleri, öğretim süreci, dinleme ve konuşma becerilerine yönelik programın güçlü ve zayıf yönleri açısından ne derece etkili ve yeterli olduğunu ortaya çıkarma amacıyla yapılmıştır. Bu bağlamda araştırmanın programının güçlü ve zayıf yönlerini ortaya koyarak ve dinleme ve konuşma becerilerini kazandırmadaki etkililiğini saptayarak özellikle öğretmenlere ve program geliştirme uzmanlarına programın yeterli ve yetersiz yanları üzerinde karar verme imkânı sunacağı düşünülmektedir.

\subsection{Araştırmanın Amacı}

$\mathrm{Bu}$ araştırmanın amacı programın bağlam-girdi-süreç ve ürün boyutlarının detaylı bir şekilde ele alınıp değerlendirilmesine imkân sağlayan BGSÜ Modelini kullanarak İlkokul 4. sınıf İngilizce dersi öğretim programının etkililiği hakkında karar vermektir.

\subsection{Sinirlilıklar}

Bu çalışma;

1) 2015-2016 eğitim öğretim yll,

2) Antalya ili merkez ilçelerine bağlı TEOG İngilizce dersi sınav sonucuna göre orta düzey olarak belirlenen bir okulda öğrenim gören 4. sınıf öğrencileri, bu sınıfta görev yapan İngilizce öğretmeni ve okul yöneticisi,

3) Ders kitabında yer alan 10 ünite içerisinden rastgele seçilen iki ünite (Cartoon Characters ve My Day),

4) Program içerisinde ağırlıklı olarak yer alan dinleme ve konuşma becerilerine yönelik belirlenen kazanımlar ile sinırlıdır.

\section{YÖNTEM}

Çalışmanın bu kısmında araştırma deseni, çalışma grubu, veri toplama araçları, veri toplama araçlarının geçerliği ve güvenirliği, veri toplama süreci ve verilerin analizi ve yorumlanması konularında açıklamalara yer verilmiştir.

\subsection{Araştırma Deseni}

İlkokul 4. sınıf İngilizce dersi öğretim programının uygulamadaki etkililiğini değerlendirmeyi amaçlayan bu çalışmada araştırma yöntemi olarak hem nicel hem de nitel veri toplama araçlarının ve analiz tekniklerinin bir arada ya da birbirlerini tamamlayıcı şekilde kullanılmasına imkan sağlayan (Tashakkori ve Teddlie, 2003) karma araştırma yöntemi desenlerinden eş zamanlı desen (yakınsayan desen) temel alınmıştır. Karma araştırma yönteminin tercih edilmesinin en önemli sebepleri arasında nitel yöntemle ulaşılacak sonuçların nicel yöntemden elde edilecek verilerle desteklemesi ve daha sağlam sonuçlara ulaşması, araştırma bulgularını üçgenlemesi ve uyumsuz görünen araştırma bulgularını ortaya çıkarması gösterilebilir.

\section{2. Çalışma Grubu}

Araştırmanın çalışma grubunu belirlemek amacıyla Antalya ili merkez ilçelerine ait 2015-2016 eğitim öğretim y1lı İngilizce dersi Temel Eğitimden Ortaöğretime Geçiş (TEOG) sınavı başarı ortalamaları temel alınmıştır. TEOG sınavı sonucunda İngilizce dersine ait aritmetik ortalamaları alt ve üst düzeyde yer alan okulların araştırmacının amacına hizmet etmeyeceği ve daha başka değişkenlerin sürece müdahil olacağı düşünüldüğünden, araştırmanın yapılacağı okulu TEOG sınavına göre orta seviyede yer alan okullardan amaçlı örnekleme yöntemi kullanılarak tercih edilen bir devlet İlkokulu oluşturmuştur. Araştırılacak olayı ayrıntılı ve derinlemesine betimlemeyi planlayan bu çalışmada adı geçen okulun 4. sınıfinda yer alan 22 öğrenci (14 erkek, 8 kı) ve 1 İngilizce Öğretmeni (Kadın) ile 1 yönetici (Erkek), 1 program geliştirme uzmanı (Erkek) ve 1 ders kitabı yazarı (Kadın) araştırmanın çalışma grubunu oluşturmuştur. Çalışmanın uygulanabilmesi için İl Milli Eğitim Müdürlüğ̈nden gerekli izinler alınmıştır. 


\subsection{Veri Toplama Araçları}

$\mathrm{Bu}$ çalışmada öğrencilerin İngilizce dersine yönelik olan ve ağırlıklı olarak programda yer alan dil becerilerinden dinleme ve konuşma becerilerine yönelik başarı testleri, gözlem ve görüşme formları kullanılmıştır. Ayrıca çalışmada yazılı dökümanlar bağlamında İlkokul 4. sınıf İngilizce dersi öğretim programı ve ders kitabı veri kaynağı olarak kullanılmış ve detaylı bir şekilde incelenmiştir. Fitzpatrick, Sanders ve Worthen (2004), değerlendirme sürecinin belirlenen amaca hizmet edebilmesi için farklı paydaşlarla görüşmeler yapılmasını ve hedef kitlenin araştırmacı tarafından gözlenmesinin önemli olduğunu ifade etmiştir. Bu amaç doğrultusunda hazırlanan veri toplama araçları ve gözlem süreci aşağıda ayrıntılı bir şekilde anlatılmıştır.

\subsection{Dinleme Becerisi Düzey Belirleme Testi}

İlkokul 4. sınıf İngilizce dersi dinleme becerisi kazanımlara ne derecede ulaşıldığını saptamak amacıyla her bir ünite için ayrı ayrı başarı testi geliştirilmiştir. Bir başarı testinin kapsamını belirlerken ölçülecek niteliklerin, dersle ilgili hedefleri ve kazanımları gösteren bir belirtke tablosunun hazırlanması gerekmektedir. (Metin, 2014). Dolayısıyla ilgili her iki ünite için de kazanımlara yönelik olarak bir belirtke tablosu hazırlanmış ve testte yer alacak sorular için bu belirtke tablosundan yararlanılmıstır. Testlerin güvenirliğini ortaya çıkarmakta farklı yöntemler kullanılmaktadır ancak bir testin güvenirliğinin bir uygulamada kestirilmesi için test içerisinde yer alan soruların birbirleri ile ne kadar tutarlı olduğunu ortaya koymada Kuder-Richardson (KR-20) formülü kullanılmaktadır (Turgut ve Baykul, 2013). Yapılan analiz sonucunda 4. Üniteye yönelik hazırlanan dinleme testinin KR 20 güvenirlik katsayısı 0.88 olarak hesaplanırken 5. üniteye yönelik hazırlanan testin ise 0.91 olarak hesaplanmıştır.

\subsection{Konuşma Becerisi Düzey Belirleme Testi}

Konuşma becerisine yönelik hazırlanan başarı testleri de 4 hafta arayla öğrencilere iki defa uygulanmıştır. Bu sürede kamera kaydına alınan öğrencilerin konuşma becerilerini değerlendirmek için Hadley (2001) tarafindan geliştirilen konuşma becerisi değerlendirme ölçeği Türkçeye uyarlanmış olup öğrencilerin konuşma becerilerini değerlendirmede kullanılmışır. Araştırmacı dışında bağımsız başka bir araştırmacı tarafından da değerlendirme ölçeği kullanılarak öğrencilerin sergiledikleri performanslar puanlanmıştır. İki puanlayıc1 arasındaki uyum 0.87 olarak bulunmuştur. Dolayısıyla puanlayıcılar arasında yüksek düzeyde bir uyum olduğu söylenebilir.

\subsection{Gözlem}

Durum tespiti yapabilme aşamasında, uygulamadaki İngilizce dersi öğretim programının ne derece etkili ve verimli uygulandığını saptayabilmek için 22 öğrenci ve İngilizce dersi öğretmeni kendi sınıflarında 10 hafta boyunca gözlemlenmiştir.. Gözlem formu, BGSÜ modelinın süreç aşaması temel alınmak kaydıyla sınıfın fiziksel ortamı, sınıf yönetimi, öğrenci-öğretmen iletişimi, kullanılan yöntem ve teknikler, kullanılan araç-gereç ve materyaller, ölçme ve değerlendirme bölümlerinden oluşmaktadır. Gözlem sonuçlarından elde edilen verilerin güvenirliğine ilişkin Kappa analizi yapılmıstır. Analiz sonunda kodlayıcılar arası uyumun kappa katsayısı 0.74 olarak bulunmuştur. Landis ve Koch (1977) kappa katsayısı 0.20’ye eşit veya bu değerden küçük ise "zayıf uyum", 0.21-0.40 aralığında ise "Ortanın altında uyum", 0.41-0.60 aralığında ise "Orta derece uyum", 0.61-0.80 aralığında ise "İyi düzeyde uyum", 0.81-1.00 aralığında ise "Çok iyi düzeyde uyum" olarak tanımlamışlardır. Dolayısıyla elde edilen değer sonucunda kodlayıcılar arasında iyi düzeyde uyum olduğu söylenebilir.

\subsection{Görüşme Formu}

$\mathrm{Bu}$ araştırmada uygulamanın yapıldığı dersin öğretmeninin, okul yöneticisinin, program geliştirme uzmanının ve kitap yazarının İngilizce dersi öğretim programının etkililiğine yönelik görüşlerini belirlemek amacıyla her biri için ayrı ayrı görüşme sorularının yer aldığı bir görüşme formu hazırlanmıştır. Görüşme formunda BGSÜ modeli çerçevesinde yer alması gereken sorular oluşturulduktan sonra form kapsam geçerliğine ilişkin uzman görüşüne sunulmuştur. 


\subsection{Veri Toplama Süreci}

Geliştirilen başarı testleri ünite işlenmeden önce ve ünite işlendikten sonra aynı gruba 4 hafta arayla araştırmacı tarafindan uygulanmıştır.

Öğrenme - öğretme sürecinde program içerisinde yer alan öğretmen ve öğrenci davranışlarının gerçekleşme düzeyini saptamak için sınıf ortamı her hafta kamera kaydına alınmıştır. Bununla beraber kayda alınan her ders içerisindeki davranışlar oluşturulan yapılandırılmış gözlem formuna kodlanmıştır. Gözlem sürecine ait veriler toplamda (10 hafta x 2 saat) 20 saatten oluşan bir sınıfin gözlenmesiyle elde edilmiştir.

İngilizce dersi öğretim programının değerlendirilmesi kapsamında dersin İngilizce öğretmenine, okul yöneticisine, bir program geliştirme uzmanına ve bir kitap yazarına BGSÜ modelinin bağlam, girdi, süreç ve ürün boyutları temel alınarak bir görüşme formu uygulanmıştır. Yapılan görüşme süreçlerinde program geliştirme uzmanı ve kitap yazarıyla yapılan görüşmeler ses kaydına alınırken ders öğretmeni ve okul yöneticisiyle yapılan görüşmeler elektronik olarak internet aracıllğıyla gerçekleştirilmiştir.

\subsection{Verilerin Analizi}

Ünite öncesinde ve sonrasında uygulanan başarı testlerinin analizinde Wilcoxon İşaretli Sıralar testi kullanılmıştır. Wilcoxon İşaretli Sıralar testi ilişkili iki ölçüm setine ait puanlar arasındaki farkın anlamlılığını test etmek amacıyla kullanılan parametrik olmayan bir testtir(Büyüköztürk, 2014). Bu testin tercih edilmesinin nedeni örneklem sayısının küçük olmasındandır. Bu analiz .05 anlamlılık düzeyinde geçekleştirilmiştir.

Kamera kaydına alınan sınıf ortamının gözlenmesi sürecinde ve görüşme yoluyla farklı paydaşlardan elde edilen verilerin analizinde nitel veri analiz süreci uygulanmışırı̇llk aşamada gözlem ve görüşme kayıtları kelimesi kelimesine yazıya aktarılmıstır. Daha sonra verilerin güvenirliğini teyit etmek için rastgele seçilen bir gözlem kaydı ve bir görüşme kaydı üç bağımsız araştırmacı tarafından daha kodlanmıştır. Verilerin güvenirliğine ilişkin yapılan Kappa analizi sonucu ortaya çıkan kodların iyi düzeyde tutarlılık gösterdiği gözlenmiştir. Aynı zamanda kodlayıcılar arası güvenirlik (Yıldırım ve Şimşek, 2013) olarak adlandırılan bu süreç kodlayıcılar arasındaki verilerin analizindeki tutarlılığı ortaya koymuştur. Kodlayıcıların arasındaki uzlaşma neticesinde tüm kayıtlar içerik analizine tabii tutulmuştur. Ortaya çıkan kodlar temalar altında sınıflandırılmıştır. Sonuç olarak bu kodlar ve alıntılar birleştirilerek yorumlanmış ve bulgular kısmında sunulmuştur.

\section{BULGULAR}

$\mathrm{Bu}$ bölümde elde edilen verilerin analiz edilmesiyle ulaşılan bulgulara yer verilmiştir. Elde edilen bulgular programın bağlam, girdi, süreç ve ürün aşamalarına göre ayrı ayrı sunulmuştur.

\subsection{Araştırmanın "Bağlam” Boyutuna İlişkin Bulgular}

Aşağıda programın yapısına, temel ilkelerine, felsefesi ve vizyonuna ilişkin doküman incelemesi ve program geliştirme uzmanı ile yapılan görüşmelerden elde edilen alıntılar sunulmuştur.

...Öğretim programmm yapısı aslında daha çok lexical syllabus dediğimiz sözcü̈k ögrretimine dayah bir yapıdadir. Temel ilkeleri ögrencilerin mümkün mertebe konuşma ve dinleme becerilerinin gelistirilmesi ve dili işlevleriyle ögrenmeleri üstüne dayanyyor. Felsefesinde Common European Framework baskin. Bunun yannda da sevdirerek dili ögretme temel

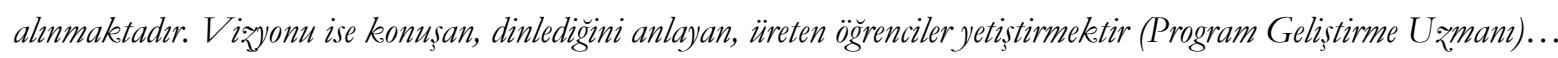

Doküman incelemesi sonucunda ise programının yapısının Avrupa dilleri öğretimi ortak çerçeve programına dayalı olduğu, sözcük öğretimini temel aldığı, tema ile ilişkilendirilmiş beceri geliştirme etkinliklerini temel aldığı, sarmal bir yapıya sahip olduğu ve iletişim temelli olduğu görülmektedir.

Program geliştirme uzmanı ile programın güçlü ve zayıf yönlerine ilişkin görüşme verileri kısaltılarak doğrudan aşağıda sunulmuştur.

...Programin her şeyden önce dünyanın en başat programlarna uygun bir şeklinde hažrlanmıştır. En az 40-50 tane

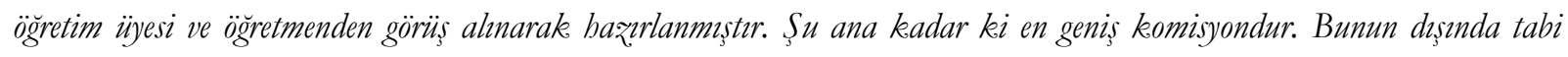
resmi olmayan yü̈lerce saatlik tarțsma, konuşma ve fikir alma da çok şekillendirmistir. Bunlar güclü yönleridir. Zayıf yönüne gelince ben ulusal sinavlarla ters düstü̈ünü̈ ve gerçekçi olmadiğm düşünüyorum. Çünkü ögrenciler netice itibariyle 
dinleme konuşma ağrrlkkh bir eğitimden geșiyorsa eğer program ölle hedefliyorsa ulusal sinavlarn da dinleme ve konușma temelli olması lažm ama ulusal sinavlar dinleme ve konusma becerilerini içermiyor (Program Gelistirme Użmani)...

Görüldüğü üzere program geliştirme uzmanının, programın teorik olarak olması gereken gibi hazırlandığını, ancak uygulamadaki sürecin hazırlanan programa yönelik yürütülmediği kanaatinde olduğu görülmektedir.

Program geliştirme uzmanı ve kitap yazarı ile yapılan görüşmelerin analizi sonucunda programda göz ardı edilen ve karşılanmayan ihtiyaçlara ilişkin elde edilen veriler kısaltılarak aşağıda sunulmuştur.

...Yalmı program gelistirme komisyonunda pedagog yer almad. Çocuk psikoloğu yer almadı ekipte. Belki o bir eksiklik. olabilir ekipte diye düsünüyorum. Kırsal yerlerle uyumsuzluklar vardr ama, bunu tek başına balledebilecek dünyada böle bir programin olduğunu düşünmüyorum (Program Geliștirme Užmanı)...

...pilotlanmamıs bir kitap kabul edemem ben. Bu kitabın pilot uygulaması yapılmadı (Kitap Yazar)...

\subsection{Araştırmanın “Girdi” Boyutuna İlişkin Bulgular}

Program geliştirme uzmanı ile programa temel oluşturan kaynaklara ilişkin yapılan görüşme verileri aşağıda doğrudan sunulmuştur.

...Program ilk önce Common European Framework'un kaynakçasinda yer alan eserler ve onun dişında dünyadaki dil ögretiminde başar kazanmış ülkelerin ders programlarm inceleyerek, temel kaynaklar oluşturduk. Bol bol tartşarak birçok

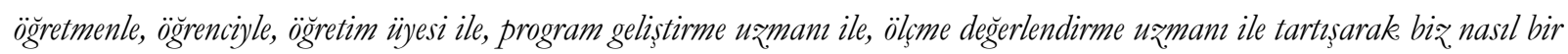
program ibtiyaçlarmız̨ karşılar sorusuna cevap aradık (Program Geliştirme Užmanı)...

Yapılan görüşmelerin analizi sonucunda Avrupa dilleri öğretimi ortak çerçeve programı, yabancı dil öğretiminde başarı kazanmış ülkelerin öğretim programları, literatür taraması sonucu ortaya çıkan ihtiyaçlar ve farklı paydaşlardan alınan görüşler olduğu tespit edilmiştir.

Program geliştirme uzmanı ve öğretmen ile programın kapsamı ile belirlenen kazanımların uyumuna ilişkin yapılan görüşme verileri aşağıda kısaltılarak sunulmuştur.

...illk olarak kazanmmlarn daha net ifade edilmeli, çünkü şu anki hali çok ywvarlak ifadelerle dolu (Öğretmen)...

...bu kazanmlara yönelik algmm değismesi amacryla yapılabilecek en önemli sey Türkiye'deki sinav sisteminde yabancr dilin ölçme ve değerlendirme sisteminin değğstirilmesidir (Ö̈̆retmen)...

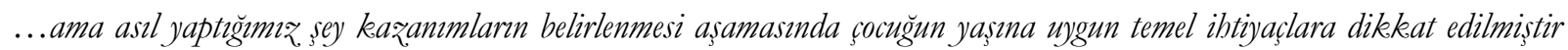
(Program Gelistirme Uzmani)...

Okul yöneticisiyle programın uygulandığı okulun bütçesine ilişkin yapılan görüşme verileri aşağıda olduğu gibi doğrudan aktarılmıştır.

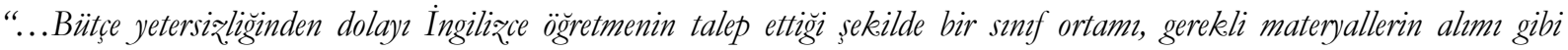
ibtiyaçlar karşslanamamaktadır. Bundan dolay äğrenci velilerinden destek beklenmektedir. Sosyo-ekonomik açıdan yetersiz. olan aile sayısı bir hayli fazla olduğundan ibtiyaçlar karşılanamamakta ve Ingilizce başarnsı istenilen düreye bir türlü gelememektedir (Okul Yöneticisi)...

Programın uygulandığı okula ayrılan bütçenin yetersiz olduğu ve bundan dolayı istenilen dil sınıfı ortamının oluşturulamadığı, bütçenin yetersiz kaldığı çoğu durumda velilerden destek alındığı ve öğrencilere bütçe yetersizliğinden dolayı sunulamayan bazı imkânlara öğretmen tarafından hazırlanan materyallerle ulaşılmaya çalışıldığının okul yöneticisi tarafindan ifade edildiği görülmektedir

\subsection{Araştırmanın "Süreç" Boyutuna İlişkin Bulgular}

Öğretim programının süreç boyutuna ilişkin elde edilen bulgular öğretim programının incelenmesi, sınıf içerisinde kamera kaydına alınan gözlemler ve İngilizce öğretmeniyle yapılan görüşmeler sonucunda elde edilmiştir. Araştırma sorularına yönelik elde dilen bulgular aşağıda sunulmuştur.

Programın uygulama aşamasında kullanılan öğretim yöntem ve tekniklerine ilişkin yapılan doküman incelemesi, gözlem ve öğretmen ile yapılan görüşme kayıtları aşağıda sunulmuştur. 
...İlk önce kullanmadiğımdan başlayayım; "Pair ve group work" ü hiç denecek kadar az kullanyorum. Dinleme ve konusma becerilerine yönelik en çok soru cevap yöntemini ve not alma yöntemini kullanyorum (Öğretmen)...

Doküman analizi sonucunda öğretim yöntem ve tekniklerinin iletişim odaklı olması, resimli kartlar kullanılması; drama, soru cevap, eşleştirme, rol yapma tekniklerinin kullanılması; dinleme ve konuşma etkinliklerine yer verilmesi ve oyunlar olduğu görülmektedir. İngilizce öğretmeni soru-cevap tekniği ile not almayı kullandığını ifade ederken gözlem sonuçları doğrultusunda öğretmenin soru-cevap, gösterip yaptırma, not alma ve düz anlatım tekniklerine başvurduğu gözlenmiştir.

Öğretim programının incelenmesi, gözlem ve öğretmenle yapılan görüşme kayıtlarının analizi sonucunda kazanımları kazandırmaya yönelik kullanılması önerilen araç-gereç ve materyallerin karikatür, kukla, grafik, poster, resimli kartlar, resimli sözlükler, tablolar ve kartpostal olduğu görülmektedir. İncelenen gözlem ve görüşme kayıtları sonucunda İngilizce öğretmenin sadece resimli kartlar, poster ve etkileşimli tahta kullandığ1 sonucuna varilmıstır.

...Akull tabta olmazsa olmaz, ancak bunun yanı sira resimli kartlar ve zaman buldukça poster kullanyorum (Ö̈̆retmen)...

Programın uygulanma sürecinde öğretmen ve öğrenci etkililiğine ilişkin gözlem verileri incelendiğinde; dinleme ve konuşma becerilerinin kazandırılmasında öğretmenin öğrencileri yönlendirme, dikkat çekme, bilgilendirme, beden dilini etkili kullanması ve öğrencilerle bire bir ilgilenme öğretmenin etkililiği açısından güçlü yönleri olarak ele alınmıştır. Zaman yönetimi, gürültü oluşumunu engelleyememe, soru cevap etkinliklerinde iletişimsizlik yaşanması, programın uygulanma sürecinde anadil kullanması ve etkinliklere öğrenci katılımını sağlayamama öğretmenin etkililiği açısından zayıf yönleri olarak değerlendirilmiştir. Öğrencilerin ise sınıf içerisinde genellikle pasif ve dinleyici olarak derslere katılım gösterdiği, öğretmenin yabancı dilde sorduğu sorulara anadil kullanarak cevap verdiği, yabancı dilde konuşurken utangaçlık hissi yaşadıkları, sınıf içerisinde yapılan alıştırmalara isteyerek katılım göstermedikleri ve sınıfta en çok kağıt dağıtma, duvara ve panoya resim asma gibi sorumlulukları severek yaptıkları gözlenmiştir.

Programın uygulama aşamasında yaşanan zorluklara ilişkin gözlem kayıtlarının ve öğretmenle yapılan görüşmelerin analizi sonucunda öğretmenin hem 4. hem de 5. Ünitenin dilbilgisi öğretiminde, konuşma becerilerine yönelik etkinliklerin planlanmasında ve öğrencilerle karşılıklı yabancı dilde iletişim kurulmasında zorluklar yaşadığı görülmüştür. Bu hususta öğretmen ile yapılan görüşme verileri aşağıda sunulmuştur.

...Öz̧ellikle dilbilgisi ögretiminde problem yaşzyorum. Dinleme ve konusma becerilerini kazandirmaya çalışırken dilbilgisi ihmal ediliyor çünkü süre yetmiyor. Kendilerini ifade etme noktasinda kullanmalar gereken bilgi ve becerilerin ögretimi konusunda özellikle sıkentı yaşıyorum. Bunu tüm üniteler için söyleyebiliriz. (Öğretmen)...

Programın etkili bir şekilde uygulanmasını engelleyen unsurlara ilişkin öğretmenle yapılan görüşme verileri aşağıda doğrudan aktarılmıştır.

...Ders saati, teknoloji, hazır bulunusluk, tekrar ve pekiştirme, ders kitabı” ana basllklarında aslinda yullardır tekrar ettiğimiz sorunlar yaşamaktayz, ve bir kisım sorunumuz sözüleceğine daha da olumsuz hale geliyor. Ders saatlerimiz geçen yuldan bu yula nedense az̧altıldı. 4. Simflarda 3 ders saatinden 2 ders saatine düşürüldü. 4. Sinflarda çok verimsiz geçiyor, yapmamı gereken hiçbir şeyi yapmaya vaktimiz yetmiyor. Bu durum çok can sıkıı. Kendi çabamla dinleme ve konusma becerilerini nasul daha etkili verebilirim diye takip ettiğim özel seminerler oluyor ve bir kusmina maddi sebeplerle katılamıyorum. Milli Eğitim bizlere ekstra is yükü çıkarmak yerine çok daha fąla eğitmeli. Tüm ögretmenler kendini

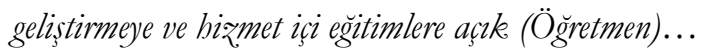

Programın uygulama sürecinde kullanılan ders kitabına ilişkin elde edilen veriler kitap yazarı ve öğretmen ile yapılan görüşmeler doğrultusunda olduğu gibi aşağıda aktarılmıştır.

....Kitabın uygulanmasımn temelinde sözcük ögretimi yatmaktadır (Kitap Yazarl)...

...Her ünitede serpiştirilmiş biçimde kültür öğretimi var. Fakat bunun güclendirilmesi lą̧m (Kitap Yąar)...

... Kendi hedef kitlemiz̨i iyi tanıyan yaz̧arlarn kaleminden çıkmıs kitaplar olması açısından avantajlı, ancak yurt dışından gelen yaymlara göre tabii ki içerike olarak gerçek hayat unsurlarm içermesi, video ve ses elementleri açısindan yetersiz̨ler. 
Görseller eskiye göre çok daba fąla ve ilgi çekici, dinleme ve konusmaya yönlendirici olmalar açısindan kesinlikle eskisinden çok daha fazla kaliteli ve dolular (Öğretmen)...

...Bu kitabın pilot uygulaması yapılmadl. Süreş şölle işledi güm 4+4+4 geldi. 2'lere kitap yetişmek zorunda. '-3-4 lere kitap yetiştirin. Müfradatı yetiștirin kitaplar yetiştirin. Okullara gidecek ögrgetmen kitaplarm yetiștirin. Öyle bir süreşti ki bu kitap yazıllkeen görseller çıkıyordu. Görsel yapıllrken iște mizanpaj yapıllyordu. Mizanpaj yapılirken ses materyalleri çlkıyordu. Yetişti mi? Yetiști. Ama etkililiğ tartışıler (Kitap Yazar)...

\subsection{Araştırmanın "Ürün” Boyutuna İlişkin Bulgular}

Öğretim programının ürün boyutuna ilişkin elde edilen bulgular dinleme ve konuşma becerilerine yönelik hazırlanan başarı testlerinin uygulanması ve program geliştirme uzmanı ile İngilizce öğretmeniyle yapılan görüşmeler sonucunda elde edilen bulgular aşağıda sunulmuştur.

\subsubsection{Dinleme Becerisine İlişkin Bulgular}

Programın uygulanması sonucunda dinleme becerilerinin öğretimine yönelik elde edilen bulgular Tablo1 ve Tablo 2'de sunulmuştur.

Tablo 1. Öğretim Öncesi ve Sonrası 4. Ünite (Cartoon Characters) Dinleme Becerileri Testi Puanlarının Wilcoxon İşaretli Sıralar Testi Sonuçları

\begin{tabular}{llllll}
\hline Sontest-Öntest & $\mathbf{n}$ & Sıra Ortalaması & Sıra Toplamı & $\mathbf{z}$ & $\mathbf{p}$ \\
\hline Negatif Sıra & 4 & 5.75 & 23 & $2.33^{*}$ & .020 \\
Pozitif Sıra & 12 & 9.42 & 113 & & \\
Eşit & 6 & & & & \\
\hline
\end{tabular}

*Negatif sıralar temeline dayalı

Öğrencilerin öğretim öncesi ve sonrası dinleme becerilerinin anlamlı bir farklılık gösterip göstermediğine ilişkin Wilcoxon işaretli sıralar testi Tablo 1'de verilmiştir. Analiz sonuçları, araştırmaya katılan öğrencilerin dinleme becerileri testinden aldıkları deney öncesi ve sonrası puanları arasında anlamlı bir fark olduğunu göstermektedir, $\mathrm{z}=2.33, \mathrm{p}<.05$. Fark puanlarının sıra ortalaması ve toplamları dikkate alındığında, gözlenen bu farkın pozitif sıralar, yani sontest puanı lehinde olduğu görülmektedir. Bu sonuçlara göre, İlkokul 4. sınıf İngilizce dersi öğretim programı içerisindeki uygulamaların öğrencilerin 4. Ünite (Cartoon Characters) içerisinde dinleme becerilerini geliştirmede önemli bir etkisi olduğu söylenebilir.

Tablo 2. Öğretim Öncesi ve Sonrası 5. Ünite (My Day) Dinleme Becerileri Testi Puanlarının Wilcoxon İşaretli Sıralar Testi Sonuçları

\begin{tabular}{llllll}
\hline Sontest-Öntest & $\mathbf{n}$ & Sira Ortalaması & Sira Toplami & $\mathbf{z}$ & $\mathbf{p}$ \\
\hline Negatif Sira & 7 & 10.29 & 72 & $1.23^{*}$ & .21 \\
Pozitif Sıra & 13 & 10.62 & 138 & & \\
Eşit & 0 & & & & \\
\hline *Negatif sıralar temeline dayalı & & &
\end{tabular}

Öğrencilerin öğretim öncesi ve sonrası dinleme becerilerinin anlamlı bir farklılık gösterip göstermediğine ilişkin Wilcoxon işaretli sıralar testi Tablo 2'de verilmiştir. Analiz sonuçları, araştırmaya katılan öğrencilerin dinleme becerileri testinden aldıkları deney öncesi ve sonrası puanları arasında anlamlı bir fark olmadığını göstermektedir, $\mathrm{z}=1.23, \mathrm{p}>$.05. Fark puanlarının sıra ortalaması ve toplamları dikkate alındı̆̆ında, gözlenen bu farkın pozitif sıralar, yani son test puanı lehinde olduğu görülmesine karşın istatistiksel açıdan bu farkın anlamlı olmadığı görülmektedir.

\subsubsection{Konuşma Becerisine İlişkin Bulgular}

Programın uygulanması sonucunda konuşma becerilerinin öğretimine yönelik elde dilen bulgular akıcılık, kelime bilgisi, yapı bilgisi ve anlaşılabilirlik açısından ayrı tablolar halinde aşağıda sunulmuştur.

Tablo 3. Öğretim Öncesi ve Sonrası 4. Ünite (Cartoon Characters) Konuşma Becerileri Testi Akıcılık Puanlarının Wilcoxon İşaretli Sıralar Testi Sonuçları

\begin{tabular}{llllll}
\hline Sontest-Öntest & $\mathbf{n}$ & Sira Ortalaması & Sira Toplamı & $\mathbf{z}$ & $\mathbf{p}$ \\
\hline Negatif Sıra & 0 & 0.00 & 0.00 & 1.41 & .157 \\
Pozitif Sıra & 2 & 1.50 & 3.00 & & \\
Eşit & 18 & & & & \\
\hline
\end{tabular}

*Negatif sıralar temeline dayalı

Öğrencilerin öğretim öncesi ve sonrası konuşma becerilerinin anlamlı bir farklılık gösterip göstermediğine ilişkin Wilcoxon işaretli sıralar testi Tablo 3'de verilmiştir. Analiz sonuçları, araştırmaya katılan öğrencilerin konuşma becerileri testinden akıcılığa ilişkin aldıkları deney öncesi ve sonrası puanları arasında anlamlı bir fark olmadı̆̆ını göstermektedir, $z=1.41, \quad \mathrm{p}>.05$. Gözlenen bu farkın 20 öğrencinin 18’inde aynı kaldığı görülmektedir. Bu sonuçlara göre, İlkokul 4. sınıf İngilizce dersi öğretim programı içerisindeki uygulamaların 
öğrencilerin 4. Ünite (Cartoon Characters) içerisinde akıcı konuşma becerisini geliştirmede önemli bir etkisi olmadığı söylenebilir.

Tablo 4. Öğretim Öncesi ve Sonrası 4. Ünite (Cartoon Characters) Konuşma Becerileri Testi Kelime Bilgisi Puanlarının Wilcoxon İşaretli Sıralar Testi Sonuçları

\begin{tabular}{llllll}
\hline Sontest-Öntest & $\mathbf{n}$ & Sira Ortalamas1 & S1ra Toplami & $\mathbf{z}$ & $\mathbf{p}$ \\
\hline Negatif Sira & 0 & 0.00 & 0.00 & 2.99 & .003 \\
Pozitif Sıra & 11 & 6.00 & 66.00 & &
\end{tabular}

Eşit 9

*Negatif siralar temeline dayalı

Öğrencilerin öğretimöncesi ve sonrası konuşma becerilerinin anlamlı bir farklılık gösterip göstermediğine ilişkin Wilcoxon işaretli sıralar testi Tablo 4'de verilmiştir. Analiz sonuçları, araştırmaya katılan öğrencilerin konuşma becerileri testinden kelime bilgisine ilişkin aldıkları deney öncesi ve sonrası puanları arasında anlamlı bir fark olduğunu göstermektedir, $\mathrm{z}=2.99, \mathrm{p}<.05$. Fark puanlarının sıra ortalaması ve toplamları dikkate alındığında, gözlenen bu farkın pozitif sıralar, yani sontest puanı lehinde olduğu görülmektedir. Bu sonuçlara göre, İlkokul 4. sınıf İngilizce dersi öğretim programı içerisindeki uygulamaların öğrencilerin 4. Ünite (Cartoon Characters) içerisinde kelime bilgilerini geliştirmede önemli bir etkisi olduğu söylenebilir.

Tablo 5. Öğretim Öncesi ve Sonrası 4. Ünite (Cartoon Characters) Konuşma Becerileri Testi Yapı Bilgisi Puanlarının Wilcoxon İşaretli Sıralar Testi Sonuçları

\begin{tabular}{llllll}
\hline Sontest-Öntest & $\mathbf{n}$ & Sira Ortalaması & Sira Toplami & $\mathbf{z}$ & $\mathbf{p}$ \\
\hline Negatif Sıra & 0 & 0.00 & 0.00 & & \\
Pozitif Sıra & 0 & 0.00 & 0.00 & $0.00^{*}$ & 1.00 \\
Eşit & 20 & & &
\end{tabular}

Öğrencilerin deney öncesi ve sonrası konuşma becerilerinin anlamlı bir farklılık gösterip göstermediğine ilişkin Wilcoxon işaretli sıralar testi Tablo 5'de verilmiştir. Analiz sonuçları, araştırmaya katılan öğrencilerin konuşma becerileri testinden yapı bilgisine ilişkin aldıkları deney öncesi ve sonrası puanları arasında anlamlı bir fark olmadığını göstermektedir, $\mathrm{z}=0.00, \mathrm{p}>.05$. Fark puanlarının sıra ortalaması ve toplamları dikkate alındığında, negatif sıralar toplamının pozitif sıralar toplamına eşit olduğu görülmektedir. Bu sonuçlara göre, İlkokul 4. sınıf İngilizce dersi öğretim programı içerisindeki uygulamaların öğrencilerin 4. Ünite (Cartoon Characters) içerisinde yapı bilgilerini geliştirmede önemli bir etkisi olmadığı söylenebilir.

Tablo 6. Öğretim Öncesi ve Sonrası 4. Ünite (Cartoon Characters) Konuşma Becerileri Testi Anlaşılabilirlik Puanlarının Wilcoxon İşaretli Sıralar Testi Sonuçları

\begin{tabular}{llllll}
\hline Sontest-Öntest & $\mathbf{n}$ & Sira Ortalaması & Sira Toplami & $\mathbf{z}$ & $\mathbf{p}$ \\
\hline Negatif Sıra & 0 & 0.00 & 0.00 & 2.64 & .008 \\
Pozitif Sıra & 7 & 4.00 & 28.00 & & \\
Eşit & 13 & & & & \\
\hline
\end{tabular}

*Negatif sıralar temeline dayalı

Öğrencilerin öğretim öncesi ve sonrası konuşma becerilerinin anlamlı bir farklılık gösterip göstermediğine ilişkin Wilcoxon işaretli sıralar testi Tablo 6'da verilmiştir. Analiz sonuçları, araştırmaya katılan öğrencilerin konuşma becerileri testinden anlaşılabilirliğe ilişkin aldıkları deney öncesi ve sonrası puanları arasında anlamlı bir fark olduğunu göstermektedir, $\mathrm{z}=2.64, \mathrm{p}<.05$. Fark puanlarının sıra ortalaması ve toplamları dikkate alındığında, gözlenen bu farkın pozitif sıralar, yani son test puanı lehinde olduğu görülmektedir. Bu sonuçlara göre, İlkokul 4. sınıf İngilizce dersi öğretim programı içerisindeki uygulamaların öğrencilerin 4. Ünite (Cartoon Characters) içerisinde anlaşılabilir bir konuşma becerisi geliştirmelerinde önemli bir etkisi olduğu söylenebilir.

Tablo 7. Öğretim Öncesi ve Sonrası 5. Ünite (My Day) Konușma Becerileri Testi Akıcllık Puanlarının Wilcoxon İșaretli Sıralar Testi Sonuçları

\begin{tabular}{|c|c|c|c|c|c|c|}
\hline Sontest-Öntest & $\mathrm{n}$ & Sira Ortalaması & S1ra Toplamı & $\mathbf{z}$ & $\mathrm{p}$ & \\
\hline Negatif Sira & 0 & 0.00 & 0.00 & & 2.45 & .014 \\
\hline Pozitif Sıra & 7 & 4.00 & 28.00 & & & \\
\hline Eşit & 13 & & & & & \\
\hline
\end{tabular}

*Negatif siralar temeline dayalı

Öğrencilerin öğretim öncesi ve sonrası konuşma becerilerinin anlamlı bir farklılık gösterip göstermediğine ilişkin Wilcoxon işaretli sıralar testi Tablo 7'de verilmiştir. Analiz sonuçları, araştırmaya katılan öğrencilerin konuşma becerileri testinden akıcıllı̆ga ilişkin aldıkları deney öncesi ve sonrası puanları arasında anlamlı bir fark olduğunu göstermektedir, $\mathrm{z}=2.45, \mathrm{p}<.05$. Fark puanlarının sıra ortalaması ve toplamları dikkate alındığında, gözlenen bu farkın pozitif sıralar, yani son test puanı lehinde olduğu görülmektedir. Bu sonuçlara göre, İlkokul 4. sınıf İngilizce dersi öğretim programı içerisindeki uygulamaların öğrencilerin 5. Ünite (My Day) içerisinde akıcı bir konuşma becerisi geliştirmelerinde önemli bir etkisi olduğu söylenebilir. 
Tablo 8. Öğretim Öncesi ve Sonrası 5. Ünite (My Day) Konuşma Becerileri Testi Kelime Bilgisi Puanlarının Wilcoxon İşaretli Sıralar Testi Sonuçları

\begin{tabular}{|c|c|c|c|c|c|c|}
\hline Sontest-Öntest & $\mathrm{n}$ & Sira Ortalamas1 & Sira Toplamı & $\mathbf{z}$ & $\mathrm{p}$ & \\
\hline Negatif Sira & 0 & 0.00 & 0.00 & & 2.76 & .006 \\
\hline Pozitif Sira & 9 & 5.00 & 45.00 & & & \\
\hline Eşit & 11 & & & & & \\
\hline
\end{tabular}

*Negatif siralar temeline dayalı

Öğrencilerin öğretim öncesi ve sonrası konuşma becerilerinin anlamlı bir farklılık gösterip göstermediğine ilişkin Wilcoxon işaretli sıralar testi Tablo 8'de verilmiştir. Analiz sonuçları, araştırmaya katılan öğrencilerin konuşma becerileri testinden kelime bilgisine ilişkin aldıkları deney öncesi ve sonrası puanları arasında anlamlı bir fark olduğunu göstermektedir, $z=2.76, p<.05$. Fark puanlarının sıra ortalaması ve toplamları dikkate alındığında, gözlenen bu farkın pozitif sıralar, yani sontest puanı lehinde olduğu görülmektedir. Bu sonuçlara göre, İlkokul 4. sınıf İngilizce dersi öğretim programı içerisindeki uygulamaların öğrencilerin 5. Ünite (My Day) içerisinde kelime bilgilerini geliştirmede önemli bir etkisi olduğu söylenebilir.

Tablo 9. Öğretim Öncesi ve Sonrası 5. Ünite (My Day) Konuşma Becerileri Testi Yapı Bilgisi Puanlarının Wilcoxon İşaretli Sıralar Testi Sonuçları

\begin{tabular}{|c|c|c|c|c|c|c|}
\hline Sontest-Öntest & $\mathrm{n}$ & Sira Ortalamas1 & S1ra Toplamı & $\mathrm{z}$ & $\mathrm{p}$ & \\
\hline Negatif Sira & 1 & 4.00 & 4.00 & & 2.30 & .021 \\
\hline Pozitif Sira & 8 & 5.13 & 41.00 & & & \\
\hline Eşit & 11 & & & & & \\
\hline
\end{tabular}

*Negatif sıralar temeline dayalı

Öğrencilerin öğretim öncesi ve sonrası konuşma becerilerinin anlamlı bir farklılık gösterip göstermediğine ilişkin Wilcoxon işaretli sıralar testi Tablo 9'da verilmiştir. Analiz sonuçları, araştırmaya katılan öğrencilerin konuşma becerileri testinden yapı bilgisine ilişkin aldıkları deney öncesi ve sonrası puanları arasında anlamlı bir fark olduğunu göstermektedir, $z=2.30, p<.05$. Fark puanlarının sıra ortalaması ve toplamları dikkate alındığında, gözlenen bu farkın pozitif sıralar, yani sontest puanı lehinde olduğu görülmektedir. Bu sonuçlara göre, İlkokul 4. sınıf İngilizce dersi öğretim programı içerisindeki uygulamaların öğrencilerin 5. Ünite (My Day) içerisinde yapı bilgilerini geliştirmede önemli bir etkisi olduğu söylenebilir.

Tablo 10. Öğretim Öncesi ve Sonras1 5. Ünite (My Day) Konusma Becerileri Testi Anlaşılabilirlik Puanlarının Wilcoxon İşaretli Sıralar Testi Sonuçları

\begin{tabular}{|c|c|c|c|c|c|c|}
\hline Sontest-Öntest & $\mathbf{n}$ & Sira Ortalaması & Sira Toplamı & $\mathrm{z}$ & $\mathrm{p}$ & \\
\hline Negatif Sira & 0 & 0.00 & 0.00 & & 2.64 & .008 \\
\hline Pozitif Sıra & 8 & 4.50 & 36.00 & & & \\
\hline Eşit & 12 & & & & & \\
\hline
\end{tabular}

$*$ Negatif sıralar temeline dayalı

Öğrencilerin öğretim öncesi ve sonrası konuşma becerilerinin anlamlı bir farklılık gösterip göstermediğine ilişkin Wilcoxon işaretli sıralar testi Tablo 10’da verilmiştir. Analiz sonuçları, araştırmaya katılan öğrencilerin konuşma becerileri testinden anlaşılabilirliğe ilişkin aldıkları deney öncesi ve sonrası puanları arasında anlamlı bir fark olduğunu göstermektedir, $z=2.30, \mathrm{p}<.05$. Fark puanlarının sıra ortalaması ve toplamları dikkate alındığında, gözlenen bu farkın pozitif sıralar, yani son test puanı lehinde olduğu görülmektedir. Bu sonuçlara göre, İlkokul 4. sınıf İngilizce dersi öğretim programı içerisindeki uygulamaların öğrencilerin 5. Ünite (My Day) içerisinde anlaşılabilir bir konuşma becerisi geliştirmelerinde önemli bir etkisi olduğu söylenebilir.

3.4.3. Programda Benimsenen Değerlendirme Yaklaşımı ve Ölçme Değerlendirme Tekniklerine İlişkin Bulgular

Program geliştirme uzmanı ve İngilizce öğretmeni ile programda benimsenen değerlendirme yaklaşımı ve ölçme değerlendirme tekniklerine ilişkin yapılan görüşmeler aşağıda doğrudan aktarılmıştır.

...proje ve portfolyo değerlendirme, öz ve akran değerlendirme ile ögretmen gözlemleri ve değerlendirmeleri tekniklerinin kullanulmasi gerekmektedir. Ancak, Netice itibariyle milli sinavlar, sinıflardaki coke kisi, ögretmenlerin ders yükü maalesef ölçme ve değerlendirme sürecinde süreç odakh en model yaklaşımlar uygulamamı̨̧ engelliyor (Program Geliştirme Uz̧mami)...

...dinleme, yazma, konuşma gibi becerileri ölçmeme açısından biz̧lerin alt kademelerdeki ders işleyişimiz̧ dabi etkilemekte ve bu becerilere yönelmek için zaman ayırmamı̨̧ zorlaştırmaktadır. Örneğin ben sonraki sinavlarmda dinleme sorayım desem, buna yönelik elimde dinleme materyali yok ve tek başıma hazırlamam da imkansız. Boşluk doldurma', Doğru/Yanlış', 'Çoktan seçmeli' ve (okuma parçasına yönelik) 'Soru Cevap’. Coktan seçmeli en çok kullandiğım teknik, nedeni de liseye geçis sinav sistemimize yönelik bu tarz sorulara cevap vermeye ögrencilerin alısmak zorunda olmalardor (Ögrretmen)... 
Buradan hareketle İlkokul 4. sınıf İngilizce dersi öğretim programında benimsenen değerlendirme yaklaşımının süreç odaklı olduğu söylenebilir. Ölçme ve değerlendirme tekniklerine ilişkin program geliştirme uzmanı proje ve portfolyo değerlendirme, öz ve akran değerlendirme ile öğretmen gözlemleri ve değerlendirmeleri tekniklerinin kullanılması gerektiğini belirtmiştir. İngilizce Öğretmeninin görüşleri ve gözlem sonuçları neticesinde ise yazılı sınavlar eşliğinde boşluk doldurma, doğru-yanlış testleri ve çoktan seçmeli sinav tekniklerini uygulandığ tespit edilmiştir.

\section{TARTIŞMA ve SONUÇ}

\subsection{Bağlam Boyutuna İlişkin Sonuç ve Tartışma}

Programın genel olarak Avrupa dilleri ortak çerçeve programına dayalı olduğu, sarmal bir yapıya sahip olup iletişim temelli olduğu, özellikle dinleme ve konuşma becerilerinin geliştirilmesini temel aldığı, eklektik bir yaklaşımla tasarlandığı ve İngilizce konuşabilen, dinlediğini veya duyduğunu anlayabilen üretken öğrenciler yetiştirmeyi hedeflediği sonuçlarına varılmıştır. Buradan hareketle programın dinleme ve konuşma becerileri bağlamında öğrenci ihtiyaçlarını temel aldığı ve öğrencilerin dili kullanırken kendilerini rahat hissedecekleri gerçekçi bir iletişim ortamı sağlamayı amaçladığı ve program içerisinde yer alan ünitelerin birbirinin devamı niteliğinde olduğu söylenebilir. Bu durum Demirtaş ve Erdem (2015)'in yapmış oldukları çalışmanın sonuçlarıyla benzerlik göstermektedir.

Programın güçlü yönleri olarak; dünyada yabancı dil öğretimi hususunda önemli başarılara imza atmış olan ülkelerin uyguladıkları programların rol model alınarak hazırlandığı ve bu hazırlanma aşamasında öğretmen ve akademisyen görüşlerinden faydalanıldığı sonuçlarına varılmıştır. Programın zayıf yönleri olarak ise; içeriğin yapılan ulusal sınavlarla uyumsuz olduğu, programın uygulanacağı farklı bölgelerdeki farklı demografik yapıların göz ardı edildiği ve toplumu yansıtan öğelere program içerisinde çok az yer verildiği sonuçlarına ulaşılmıştır. Buradan hareketle programın hazırlanma aşamasında öğrenci ihtiyaçları temel alınmasına ve örnek programlar eşliğinde öğretmen ile akademisyen görüşlerine yer verilmesine rağmen toplumun sahip olduğu özelliklerin gerek programa gerekse program içerisinde kullanılan ders kitabına yansımamış olması ögrencilerin bu durumu içselleştirilmeleri noktasında bir engel olarak gösterilebilir. Bu durum Eğinli ve Çakır (2011)'in yapmıs oldukları çalışmada toplum kültürünün okul kültürüne ve programa yansıtılması sonuçları ile benzerlik göstermektedir.

Programda göz ardı edilen ve karşılanmayan ihtiyaçlara bakıldığında öncelikle programın pilot uygulamasının yapılmadan ve programın uygulanacağı öğrenci grubunun yaş uygunluğu test edilmeden tüm ülkede uygulandığı, kırsal bölgelerde yaşayan öğretmen ve öğrencilerin ihtiyaçlarının dikkate alınmadığ1, kazanımların belirlenme aşamasında Türk kültürünün göz ardı edildiği, program geliştirme ve kitap yazma komisyonunda pedagog ve çocuk psikoloğunun yer almadığı sonuçlarına varılmıştır. Buradan hareketle pilot uygulaması yapılmadan programın uygulamaya konulması öğretmen, öğrenci ve programın gereksinimlerini belirleme noktasında sorunlara yol açabileceği ifade edilebilir. Program içerisinde kullanılan ders kitabının içeriğinin ve dinleme ve konuşma becerilerine yönelik hazırlanan etkinliklerin çocukların yaş grubuna uygunluğu test edilmeden uygulanması, öğretmenlerin de bu yaş grubundaki öğrencilere İngilizce öğretme noktasında sıkıntılar yaşayabileceği endişesini doğurmaktadır. Bu durum Küçüktepe, Küçüktepe ve Baykın (2014) tarafından yapılan ikinci sınıf İngilizce dersi ve programına ilişkin öğretmen görüşlerinin incelenmesi adlı çalışmanın sonuçları ile de benzerlik taşımaktadır. Yaş seviyesinin öğrenme üzerinde önemli bir rolü olduğu gerçeği göz önünde bulundurulursa (K1lıç, 2013) program geliştirme ve kitap yazma komisyonunda pedagog ve çocuk psikologların bulunmaması İlkokul 4. sınıf öğrencilerine yönelik belirlenen kazanımların öğrenciye uygunluğu açısından şüphelere neden olduğu söylenebilir. Programın hazırlanma sürecinde kırsal bölgelerde yaşayan öğretmen ve öğrencilerin ihtiyaçlarının göz önüne alınmamasının, bu bölgelerde yürütülen programın kentte yürütülene nazaran belirlenen kazanımları gerçekleştirme hususunda daha az başarılı olacağ1 söylenebilir. Bu durum Ferreria ve Gignoux (2010) tarafindan yapılan Eğitimde Firsat Eşitsizliği: Türkiye Örneği adlı çalışma raporunun sonuçları ile paralellik göstermektedir. 


\subsection{Girdi Boyutuna İlişkin Sonuç ve Tartışma}

Programa temel oluşturan kaynakların, yapılan analizler sonucunda Avrupa dilleri ortak çerçeve programı, yabancı dilde başarı kazanmış ülkelerin öğretim programları, literatür taraması sonucu dil öğretiminde ortaya çıkan ihtiyaçlar ve farklı paydaşlardan alınan görüşler olduğu sonucuna varılmıştır. Bu bağlamda İlkokul 4. sınıf İngilizce dersi öğretim programının öğrencilerin dinleme ve konuşmaya dayalı becerilerinin geliştirilmesinde kapsamlı bir hazırlanma sürecinden geçtiği söylenebilir. Özellikle program geliştirme uzmanının belirttiği üzere İngiltere, Finlandiya, Kanada gibi yapılandırmacı yaklaşımdan etkilenen ülkelerin öğretim programlarından faydalanıldığı ve bu görüşün temel alınarak içeriğin hazırlandığı söylenebilir. Ortaya çıkan bu durum Akınoğlu (2005) tarafından yapılan ve Türkiye'de uygulanan ve değişen eğitim programlarındaki farklılıkları ortaya koyan çalışmanın sonuçları ile benzerlik göstermektedir.

İlkokul 4. sınıf İngilizce dersi öğretim programının ağırlıklı olarak dinleme ve konuşma becerilerini temel aldığı ve sarmal programlama yaklaşımı (2. ve 3. sınıfların devamı niteliğinde) ile birlikte bu becerilere yönelik belirlenen kazanımlara erken yaştaki ögrenci grubuna kazandırılmak üzere programda yer verildiği sonuçlarına ulaşılmışır. Dinleme ve konuşma becerilerinin dört temel beceriden en zor gelişenleri ve bu becerilerin erken yaşta kazandırılması gerçeği göz önünde bulundurulduğunda (Od, 2013) programın kapsamı ve kazanımları arasındaki uyumun yüksek düzeyli olduğu söylenebilir. Ancak programda dinleme ve konuşma becerilerine yönelik hazırlanan metinlerin kısa ve açı olması gerektiği ifade edilmesine rağmen ders kitabında yer alan ses kayıtlarının bu özelliği taşımadığı sonucuna varılmıştır. Buradan hareketle hazırlanan dinleme ve konuşma metinlerinin çocukların gelişim seviyeleri dikkate alınmadan hazırlandığı ve pilot uygulaması yapılmadan sürece dahil edildiği için kazanımların öğrencilerde arzu edilen seviyede gerçekleşmesi noktasında sıkıntılar yaşanabileceği söylenebilir.

Okul yöneticisi ile yapılan görüşmeler sonucunda programın uygulandığı okulun bütçesinin ve yardımc1 kaynaklarının yetersiz olduğu ve bundan dolayı istenilen dil öğrenme ortamının oluşturulamadığı, bütçenin yetersiz kaldığı çoğu durumda ise öğretmen ve veli işbirliği içerisinde ihtiyaçların giderilmeye çalışıldığ1 sonuçlarına ulaşılmıştır. Dolayısıyla, bütçe yetersizliğinin programın etkili bir şekilde yürütülmesine ve nitelikli eğitim verilmesi hususunda sorunlara zemin hazırlayacağı söylenebilir. Ortaya çıkan bu durum Demirpolat (2015) ile Ayrangöl ve Tekdere (2014) tarafından yapılan çalışmaların sonuçlarıyla benzerlik göstermektedir.

Programın uygulandığı okul ve sınıf ortamına ilişkin elde edilen veriler incelendiğinde okulun kırsal bir bölgede yer aldığı ve öğrencilerin sınıf ortamı dışında İngilizceyi pratik olarak kullanabilecekleri başka bir alan olmadığı sonucuna varılmıştır. Bu bağlamda kırsal ve kentsel yerlerde verilen eğitimin ve bu bölgelerde yer alan okulların sahip olduğu donanımların ve şartların öğrenci başarısıyla ve verilen eğitimin kalitesiyle doğrudan bir ilişki içerisinde olduğu söylenebilir. Yapılan farklı araştırmalarda da benzer sonuçlara ulaşıldığı görülmüştür (Atalay ve Anagün, 2014; Hennessy Harrison ve Wamakote, 2010). Bunun yanında sinıf ortamı her ne kadar görsellerle birlikte programın uygulanmasına zemin hazırlasa da sınıf genişliğinin farklı etkinlikler yapma noktasında 22 kişilik bir öğrenci grubuna göre küçük kaldığı tespit edilmiştir. Duvarlardaki ses yalıtımının iyi olmamasının ise özellikle dinleme metinlerinin öğrenciler tarafından iyi düzeyde anlaşılmasına engel olduğu gözlenmiştir. Sınıfta donanım olarak özellikle dinleme becerilerine yönelik öğretmenin ve öğrencilerin faydalandığı en önemli aracın ise etkileşimli tahta olduğu ve programın etkileşimli tahta aracıllğıyla yürütüldüğü sonuçlarına varılmıstır. Buradan hareketle barındırdığı görsel ve işitsel öğelerle birlikte etkileşimli tahtanın öğretmenin ve öğrencilerin İngilizce dersindeki en önemli yardımcı kaynağı olduğu söylenebilir. Ulaşılan bu sonuç Gündoğdu (2014) tarafından yapılan bir öğretme-öğrenme aracı olarak akıllı tahta adlı çalışmadaki akıllı tahtanın eğitim sürecindeki önemine dair elde ettiği sonuçlar ile benzerlik göstermektedir.

\subsection{Süreç Boyutuna İlişkin Sonuç ve Tartı̧̧ma}

İlkokul 4 sınıf İngilizce dersi öğretim programının uygulama süreci öğretim yöntem ve teknikleri açısından ele alındığında farklı kaynaklardan elde edilen bulguların paralellik göstermediği sonucuna ulaşılmıştır. Öğretim programında çocuklara iletişim odaklı etkinlikler yapılmasının yanı sıra drama, rol yapma, oyun oynama, eşleştirme, soru-cevap gibi yöntem ve tekniklerin kullanılması önerilirken (MEB, 2013) öğretmenin bu süreçte daha çok düz anlatım, gösterip yaptırma ve soru cevap tekniklerini kullandığ1 
görülmüştür. Kazandırılacak davranışa uygun öğrenme ve öğretme yönteminin kullanılması ilkesi göz önünde bulundurulduğunda (Sönmez ve Alacapınar, 2015) programın öğrencilere bilgiyi yaparak yaşayarak yapılandırabilecekleri bir öğrenme ortamı sağlamayı hedeflediği ancak uygulama boyutunda bu durumun tam olarak gerçekleşemediği söylenebilir.

Programın uygulama sürecinde kullanılan araç-gereç ve materyallere bakıldığında farklı kaynaklardan elde edilen bulguların paralellik göstermediği sonucuna ulaşılmıştır. Öğretim programında karikatür, kukla, grafik, poster, resimli kartlar, resimli sözlükler, tablolar, kartpostal gibi araçlardan faydalanılması gerektiği belirtilirken (MEB, 2013) öğretmenin resimli kartlar, poster ve ağırlıklı olarak akıllı tahta aracılığıyla dersi yönettiği gözlemlenmiştir. Araç-gereç ve eğitim teknolojilerinin temel amacının etkili ve kalıcı bir öğrenme ile kazanımların öğrencide gerçekleşmesini sağlamak ve birden fazla etkinlikte işe koşulabilmek (Sönmez ve Alacapınar, 2015) ilkeleri göz önünde bulundurulduğunda sınıf içinde kullanılan araç-gereçlerin dineme ve konuşma becerilerinin öğrencilere kazandırılma noktasında yeterli olmadığı söylenebilir. Bu durum Can ve Can (2014) tarafından Türkiye'de ikinci yabancı öğretiminde karşılaşılan sorunlar adlı çalışmanın sonuçları ile benzerlik göstermektedir.

Programın uygulanma sürecinde öğretmen etkililiği güçlü ve zayıf yönler açısından değerlendirilmiştir. Öğretmenin sınıf içerisinde öğrencileri yönlendirme, dikkat çekme, öğrenciyi konu hakkında bilgilendirme, beden dilini etkili kullanma ve öğrencilerle bire bir ilgilenme özellikleri güçlü yönleri olarak ele alınmıştır. Ancak zamanı etkili kullanamama, gürültü oluşumunu engelleyememe, uygulama aşamasında anadil kullanma ve derse öğrenci katılımını sağlayamama öğretmenin zayıf yönleri olarak ele alınmıştır. Bu bağlamda öğretmenin öğrencilerle ilgilenme noktasında özenle hareket ettiği ancak sınıf yönetimi bağlamında yetersiz kaldığı söylenebilir. Yapılan 10 haftalık gözlem sürecinde öğretmenin zamanı etkili kullanması noktasında sıkıntılar yaşadığı ve kendisiyle yapılan görüşmeler sonucunda da programın haftada 2 ders saati içinde yürütülmesinin çok zor olduğu sonuçları birbirlerini destekler niteliktedir. Bu durum İngilizce dersine ayrılan sürenin yetersiz olduğunu ortaya koyan farklı çalışmaların Cihan ve Gürlen (2013)'in ulaşmıs oldukları sonuçları ile benzerlik göstermektedir. Özellikle öğretim programında İngilizceyi kullanarak ve öğrenciye sevdirilerek dersin sürdürülmesi hedeflenirken (MEB, 2013) öğretmenin anadil kullanması veya İngilizce ifade ettiği durumları aynı anda Türkçeye çevirmesi dinleme ve konuşma becerilerinin öğrenciye kazandırılmasında noktasında istenmeyen bir durum olarak ifade edilebilir. Hengirmen (2006)'in çeviri yöntemi ile dil öğretimine maruz kalan öğrencilerin konuşma ve dinleme becerileri yönünden problem yaşayacağını belirtmesi bu sonucu destekler niteliktedir.

Öğrencilerin derse katılımı ele alındığında genellikle İngilizce konuşurken utangaçlık hissi yaşadıkları, İngilizce sorulan bir soruya Türkçe cevap vermeye çalıştıkları, derse katılımdan çok ders dışı faaliyetlere daha ilgi duydukları sonuçlarına ulaşılmıştır. Öğretmen ile yapılan görüşme ve sınıfın gözlenmesi sonucunda ders kitabında yer alan etkinliklerin ve resimli kartların işlevsel olmadığı ve öğrenciler için soyut kaldığı gözlenmiştir. $\mathrm{Bu}$ bağlamda çoğu öğrencinin derse isteyerek katılım sağlamadığı ve bunun sonucunda bilgiye erişme noktasında yetersiz kaldıkları için dinlediğini anlamada ve kendini ifade etmede sıkıntılar yaşadığı söylenebilir. Bu durum Merter, Şekerci ve Bozkurt (2014) tarafindan İngilizce öğretmenlerinin ikinci sınıf İngilizce dersine ilişkin görüşlerinin değerlendirilmesi adlı çalışmanın sonuçlarıyla benzerlik göstermektedir.

Programın uygulanma sürecinde öğretilmesinde zorluk yaşanan konu ve kazanımlar ele alındığında özellikle hem 4. (Cartoon Characters) hem de 5. (My Day) ünitelerinin dilbilgisi öğretiminde, konuşma becerilerine yönelik etkinlik planlanmasında ve öğrencinin İngilizce olarak kendisini veya bir başkasını basit ve kısa cümlelerle ifade etme hususunda sıkıntılar yaşandığı sonuçlarına ulaşılmışır. Bu bağlamda öğretmenin dilbilgisi öğretiminin yanı sıra özellikle konuşma becerilerine yönelik belirlenen kazanımları öğrenciye kazandırma noktasında zaman sıkıntısından dolayı pekiştirme imkanını bulamaması, fiziksel ortam ve materyal eksikliği gibi faklı değişkenlerden dolayı zorluklar yaşadığı söylenebilir. Bu durum Erdoğan (2005) tarafindan yapılan 4. ve 5. sınıflarda uygulanan İngilizce dersi öğretim programının değerlendirilmesi adlı çalışmanın sonuçları ile benzerlik göstermektedir. 
Programın etkili bir şekilde uygulanmasını engelleyen unsurlar ele alındığında ders saatinin hem dinleme hem de konuşma becerilerine ilişkin kazanımları kazandırma noktasında yetersiz kaldığı, öğrencilerin derse hazırlıksız geldiği, ders kitabının çocukların yeterince ilgisini çekmediği, sınıfın fiziksel ortamı ve okulun bütçe kapsamında sağladığı kısıtlı olanaklar olduğu sonucuna varılmıştır. Öğretmenle yapılan görüşme sonucunda özellikle MEB’in okulun, öğretmenin ve öğrencilerin sahip olduğu şartları ve programın asıl amaçlarını göz ardı ederek öğretmene ek bir iş yükü çıkarmasının (örneğin bitişik eğik yazı uygulamasının öğrenilmesi ve öğretilmesi gibi) öğretmenin süreç içerisinde etkili olmasını engelleyen başlıca unsurlardan biri olduğu sonucuna varılmıştır. Bu bağlamda yapılan görüşme ve gözlem kayıtları neticesinde program içerisinde belirlenen kazanımların gerekli olduğu ancak okul ve sınıfın fiziksel ortamının bunları gerçekleştirmeye uygun olmadığ1 söylenebilir. Dinleme ve konuşma becerilerini kazandırmada etkileşimli tahta dışında faydalanabilecek başka bir teknolojik donanımın olmamasının ve ders saati yetersizliğinin öğrenme ve öğretme süreçlerinin uygulanabilir olmasında önemli engeller olduğu ifade edilebilir. Ders kitabının programın amaçlarını gerçekleştirme bağlamında içerdiği etkinliklerin soyut kaldığı ve öğrencilerin gelişim ve kültürel özelliklerinin göz ardı edilerek hazırlandığı söylenebilir. MEB ve okul arasındaki iletişimsizliğin ise programın amaçlarını gerçekleștirmede uygulayıcı rolde olan öğretmeni zor durumda bıraktığı söylenebilir. Ortaya çıkan bu durumlar farklı araşturmaların (Demirtaş ve Erdem, 2015; Cihan ve Gürlen, 2013) sonuçları ile benzerlik taşımaktadır.

Programın uygulanma sürecinde kullanılan ders kitabı güçlü ve zayıf yönler açısından değerlendirilmiştir. Ders kitabının güçlü yönleri olarak; görsel öğelere fazla yer verildiği, dinleme ve konuşma becerilerine yönelik hazırlandığı ve öğrencilere ek alıştırmalar imkanı sunduğu sonuçlarına ulaşılmıştır. Ders kitabının zayıf yönleri olarak ise; video ve ses unsurları açısından yetersiz olması, Türk kültürünü yansıtan öğelere yer verilmemiş olmaması, hazırlanma sürecinde yaş grubunun gelişim özelliklerinin dikkate alınmaması ve kitabın uygulamaya konulmadan önce pilot çalışmasının yapılmamış olması sonuçlarına varılmıştır. Bu bağlamda kitabın görsel öğelere yer vererek erken yaştaki çocukların ilgisini çekmeye çalıştığı ve programın dinleme ve konuşma becerilerine ilişkin hedeflere yönelik hazırlandığı söylenebilir. Ancak, hazırlanan kitabın gerçek yaşam unsurlarını ve programın uygulandığı ülkenin ve bölgelerin yerel özelliklerini içermemesi öğrenciler için çoğu etkinlik ve alıştırmaların soyut kalmasına neden olduğu söylenebilir. Bu durumun Alkan ve Arslan (2014) tarafından yapılan ikinci sınıf İngilizce öğretim programının değerlendirilmesi adlı çalışmanın sonuçlarıyla benzerlik taşıdığı ifade edilebilir. Özellikle erken yaştaki çocuklara dinleme ve konuşma becerilerini kazandırmada kapsamlı bir süreç içerisinde hazırlanan ders kitabının kitap yazarının belirttiği üzere pilot uygulamasının yapılmadan eğitim-öğretim sürecine dahil edilmesi düşündürücüdür. Buradan hareketle ders kitabının tüm ülke çapında genelleştirilmesi ve sürdürülmesi konusunda endişe yarattığı söylenebilir.

\section{3. Ürün Boyutuna İlişkin Sonuç ve Tartışma}

Dinleme becerilerine yönelik 4. ve 5. ünite kapsamında yapılan öntest ve sontest sınavlarının analizi sonucunda öğrencilerin almış oldukları puanlar arasında istatistiksel açıdan anlamlı bir fark bulunmuştur. Bu fark, programın etkililiği konusunda başlangıçta önemli bir sonuç olarak görülebilir, ancak ayrıntılı bir analize gidince program, her iki ünitede yer alan kazanımları öğrencilerin büyük çoğunluğuna kazandırmada etkili olamamıştır. Özellikle öğretmenin süreç boyutunda dinleme becerilerini öğrenciye nasıl kazandıracağı hususunda yeterince hizmet içi eğitim almamıs olması ve ders saatinin yetersizliği noktasında sıkıntılar yaşaması ortaya çıkan bu durumun en önemli nedenleri olarak gösterilebilir. Bu durumun yanı sıra söz konusu program okuma-yazma etkinliklerinin yaptırılmasından ziyade dinleme ve konuşma becerilerine yönelik etkinliklere ağırlık verilmesi gerektiğini belirtmektedir. Ancak, sınıf içi uygulamaların genellikle okuma ve yazma temelli olduğu sonucuna ulaşılmıştır. Yaşanılan bu durumun nedenlerinin öğretim programının sadece süreç boyutunda yer alan uygulamalardan değil aynı zamanda bağlam-girdi-süreç arasındaki ilişkinin birbirlerini besleme noktasındaki yetersizliklerinden kaynaklandığı söylenebilir.

Konuşma becerilerine yönelik 4. ve 5. ünite kapsamında yapılan öntest ve sontest sonuçları kelime bilgisi, yap1 bilgisi, akıcılık ve anlaşılabilirlik değişkenleri açısından ayrı ayıı değerlendirilmiştir. Yapılan sınavların analizi sonucunda 4. ünitede yer alan kazanımları öğrenciye kazandırma noktasında kelime bilgisi ve anlaşılabilirlik açısından öğrencilerin almış oldukları puanlar arasında anlamlı bir fark bulunmasına rağmen yapı bilgisine ve 
akıcılığa ilişkin alınan puanlar arasında anlamlı bir fark bulunmadığı sonucuna varılmıştır. Bu durum program içerisindeki uygulamaların kelime bilgisi ve anlaşılabilirlik açısından etkili olduğu; yapı bilgisi ve akıcılık bağlamında ise etkili olmadığını göstermektedir. 5. Üniteye ilişkin elde edilen öntest ve sontest puanları arasında ise yapı bilgisi, akıcılık, kelime bilgisi ve anlaşılabilirlik değişkenleri açısından anlamlı bir fark olduğu tespit edilmiştir. Buradan hareketle program içerisindeki uygulamaların 5.ünitede yer alan konuşma becerilerine yönelik kazanımları öğrenciye kazandırma noktasında etkili olduğu ifade edilebilir. İstatistiksel olarak programın genel olarak konuşma becerilerini kazandırma noktasında etkili olduğu görülmesine rağmen her iki ünitede de yer alan kazanımları öğrencilerin büyük çoğunluğuna kazandırmada etkili olmadığı görülmüştür.

Konuşma becerilerini ölçmek için geliştirilen derecelendirme ölçeğinde sınıfin genelinin 0-4 "yetersiz" aralığında kaldığı, artış gösterenlerin ise 4-8 “orta” aralığında olduğu sonucuna varılmıştır. Dolayısıyla öğrencilerin konuşma becerilerinde arzu edilen seviyeye ulaşamadıkları söylenebilir. Buradan hareketle İngilizce öğretiminde konuşma becerisini geliştirmeye yönelik okulun ve sınıfın sahip olduğu şartlar ile öğrencilerin bulunduğu ortamın iletişimsel bir alana sahip olması gerekliliği göz önüne alındığında (Murcia ve Goodwin 1991) ortaya çıkan durumun kaçınılmaz olduğu söylenebilir. Öğretmenin her iki ünitede de konuşma becerilerine yönelik etkinlik yapmaması ve bu durumun gerekçesi olarak da zaman yetersizliğini ifade etmesi ortaya çıkan sonucun önemli bir nedeni olarak gösterilebilir. Aynı zamanda sınıf içerisinde görsel materyallere sayıca çok fazla yer verilmesine rağmen tercih edilen görsellerin ilgili ünitelerle ilişkili olmaması öğrencilerin bu beceriye yeterince hakim olamamasında bir eksiklik olarak gösterilebilir. Wright (1990) ve Açıköz (2005)'in vurguladı̆̆1 gibi öğrencilerin konuşma becerilerine istenilen düzeyde hakim olabilmesi için onlara yol gösterici ve konuşacakları konu hakkında akıllarında kalabilecek görseller kullanılmalıdır.

Dinleme ve konuşma becerilerini ölçme ve değerlendirme noktasında benimsenen değerlendirme yaklaşımı ve ölçme değerlendirme tekniklerine bakıldığında öğretim programının incelenmesi ve program geliştirme uzmanı ile yapılan görüşmelerin analizi sonucunda süreç odaklı bir değerlendirme yaklaşımının ele alındığ1 görülmüştür. İngilizce öğretmeni bu konuda görüş bildirmez iken analiz edilen gözlem sonuçları doğrultusunda daha çok sonuç odaklı bir değerlendirme yaklaşımı benimsendiği görülmüştür. Programda kullanılan ölçme ve değerlendirme tekniklerine bakıldığında program geliştirme uzmanı ve öğretim programı proje ve portfolyo değerlendirme, öz ve akran değerlendirmesi, öğretmen gözlemleri ve değerlendirmeleri, kalem-kağıt sınavları tekniklerinin kullanılması gerektiğini belirtmiştir. İngilizce öğretmeni ile yapılan görüşme ve sınıf içi gözlem sonuçlarının analiz edilmesiyle daha çok kalem-kağıt sınavlarından boşluk doldurma, doğruyanlış, çoktan seçmeli testler kullanıldığı görülmüştür. Buradan hareketle, ölçme ve değerlendirme açısından programın uygulanma aşamasında sıkıntılar yaşandığı, öğretmenin bu alanda yeterli bilgiye sahip olmadığı, programın hedeflerine ve kazanımlanına uygun bir değerlendirme sürecinin gerçekleşmediği ve düzenli bir öğrenci gelişiminin izlenmediği sonucuna varılmıştır. Bu durum Yıldıran ve Tanrıseven (2015) tarafindan İngilizce dersi öğretim programlarına yönelik yapılan farklı çalışmaların sonuçları ile benzerlik taşımaktadır.

\section{5. ÖNERİLER}

1- Programın hazırlanma aşamasında bölgelerin demografik özellikleri dikkate alınmalı ve içerik bu bölgelerin sahip olduğu farklı özelliklere göre ayrı ayrı hazırlanmalıdır.

2- Programın tüm ülkede uygulaması gerçekleşmeden önce pilot uygulamasının yapılması gerekmektedir.

3- Öğretmenlere dinleme ve konuşma becerilerini öğrenciye kazandıracak uygun ortamların ve gerekli teknik donanımın sağlanması gerekmektedir.

4- Değerlendirme sürecinde kalem-kağıt sınavlarının yanı sıra rubrik, portfolyo, akran değerlendirme gibi süreç değerlendirmeye yönelik teknikler de kullanmalıdır.

5- Ülkemizde yapılan 4+4+4 kademeli ve zorunlu eğitim reformu ile birlikte sistemsel bir değişim sürecine giren yabancı dil öğretim programının etkililiğinin ortaya çıkarılması bağlamında bu modeli temel alan gelişmiş ülkelerde uygulanan programlar ile benzerlik ve farklılıklarını ortaya koyan çalışmalar yapılabilir.

6- Kentsel ve kırsal bölgelerden belirlenecek okul veya okulların yabancı dil öğretimindeki başarılarına yönelik okul karşılaştırılmasını temel alan çalışmalar yapılabilir. 


\section{KAYNAKÇA}

Açıkgöz, K.Ü. (2005). Etkili öğrenme ve öğretme (6. Bask1). İzmir: Eğitim Dünyası Yayınları.

Akınoğlu, O. (2005). Türkiye'de uygulanan ve değişen eğitim programlarının psikolojik temelleri. M.Ü. Atatürk Eğitim Fakültesi Eğitim Bilimleri Dergisi, 22, 31-46.

Alkan, M.F. ve Arslan, M. (2014). İkinci sınıf İngilizce öğretim programının değerlendirilmesi. Uluslararası Ĕ̆itim Programları v Öğretim Çalışmalanı Dergisi, 4, 7, 87-99.

Aslan, N. (2008). Dünyada erken yaşta yabancı dil uygulamaları ve Türkiye'deki durum. Çukurova Üniversitesi Eğitim Fakültesi Dergisi, 35, 3, 1-9.

Atalay, N. ve Anagün, Ş.S. (2014). Kırsal alanlarda görev yapan öğretmenlerin bilgi ve iletişim teknolojilerinin kullanımına ilişkin görüşleri. Eğitimde Nitel Araştırmalar Dergisi, 2, 3, 9-27.

Ayrangöl, Z. ve Tekdere, M. (2014). Türkiye ve OECD ülkelerinde yapılan eğitim harcamalarının karşılaştırmalı analizi. LAÜ Sosyal Bilimler Dergisi, 2, 1-30.

Broughton, G., Brumfit, C., Flavell, R., Hill, P. ve Pincas, A. (2003). Teaching English as a foreign language (2. Bask1). London: Routledge.

Büyüköztürk, Ş. (2014). Sosyal bilimler için veri analizi el kitabı (22. Bask1). Ankara: Pegem Akademi Yayinc1lik.

Can, E. ve Can, C.I. (2014). Türkiye'de ikinci yabancı dil öğretiminde karşılaşılan sorunlar. Trakya Üniversitesi Eğitim Fakültesi Dergisi, 4, 2, 43-63.

Cihan, T. Ve Gürlen, E. (2013). İlköğretim 5. sınıf İngilizce dersi öğretim programına ilişkin öğretmen görüşleri. Anadolu Üniversitesi sosyal Bilimler Dergisi, 13, 1, 131-146.

Crystal, D. (2003). English as a global language (2. Bask1). United Kingdom: Cambridge University Press.

Çetintaş, B. (2010). Türkiye'de yabancı dil eğitim ve öğretiminin sürekliliği. Journal of Language and Linguistic Studies, 6(1), 65-74.

Demirezen, M. (2003). Yabancı dil ve anadil öğreniminde kritik dönemler. Dil Dergisi, 118, 5-15.

Demirpolat, B.C. (2015). Türkiye’nin yabancı dil öğretimiyle imtihanı sorunlar ve çözüm önerileri. İstanbul: Turkuvaz Matbaacilik.

Demirtaş, Z. ve Erdem, S. (2015). 5. sınıf İngilizce dersi öğretim programı: Güncellenen programın bir önceki programla karşılaştırılması ve programa ilişkin öğretmen görüşleri. Sakarya Üniversitesi Eğitim Dergisi, $5,2,55-80$.

Egel, İ. P. (2009). English language learning and teaching styles in two Turkish primary schools. Social Behavior and Personality, 37(8), 1117-1128.

Eğinli, A.T. ve Çakır, S.Y. (2011). Toplum kültürünün kurum kültürüne yansıması. Sosyal ve Beşeri Bilimler Dergisi, 3, 2.

Erden, M. (1998). Eğitimde program değerlendirme (3. Bask1). Ankara: Anı Yayıncılık.

Erdoğan, V. (2005). An evaluation of English curriculum implemented at the 4th ve 5th grade primary schools: The view of the teachers and the students. Yayınlanmamıs yüksek lisans tezi, Mersin Üniversitesi Sosyal Bilimler Enstitüsü, Mersin.

Ferreria, F.H.G. ve Gignoux, J. (2010). Eğitimde fırsat eşitsizliği: Türkiye örneği. Ankara.

Fitzpatrick, J. L., Sanders, J. R., ve Worthen, B. R. (2004). Program evaluation: Alternatives, approaches and practical guidelines (3. Bask1). Boston: Pearson Education Inc.

Gündoğdu, T. (2014). Bir öğretme-öğrenme aracı olarak akıllı tahta. Akademik Sosyal Araştırmalar Dergisi, 2, 6, 392-401.

Hadley, A. O. (2001). Teaching language in context. Boston: Heinle \& Heinle.

Haznedar, B. (2003). 'Neden erken yaşta yabancı dil eğitimi’. Türk Eğitim Sisteminde Yabanc1 Dil Eŭitimi ve Kalite Arayışları, İrfan Erdoğan (Haz.), 119-130, İstanbul: Özel Okullar Derneği Yayınları.

Hengirmen, M. (2006). Yabanc1 dil öğretim yöntemleri ve tömer yöntemi. Ankara: Engin Yayıın Evi.

Hennessy, S., Harrison, D. ve Wamakote, L. (2010). Teacher factors influencing classroom use of ICT in subSaharan Africa. Itupale Online Journal of African Studies, 2, 39-54.

Karakoç, C. (2007). Okul öncesi eğitimde ana sınıflanı İngilizce dersi İçin bir öğretim programı önerisi. Yayımlanmamış yüksek lisans tezi, İnönü Üniversitesi Sosyal Bilimler Enstitüsü, Malatya.

Kılıç, M. (2013). Öğrenmenin doğası. B. Yeşilyaprak (Editör). Eğitim psikolojisi gelişim öğrenme-öğretim (s. 166-196). Pegem Akademi Yayıncilik: Ankara.

Kurt, A. ve Erdğan, M. (2015). Program değerlendirme araştırmalarının içerik analizi ve eğilimleri; 2004-2013 y1llar1 aras1. Eğitim ve Bilim, 40, 178, 199-224.

Küçüktepe, C., Küçüktepe S.E. ve Baykın, Y. (2014). İkinci sınıf İngilizce dersi ve programına ilişkin öğretmen görüşlerinin incelenmesi. Hasan Ali Yücel Eğitim Fakültesi Dergisi, 11, 22, 55-78. 
Landis, J. R. ve Koch, G. G. (1977). The measurement of observer agreement for categorical data. Biometrics, $33,159-174$

MEB A.P.K. Kurulu Başkanlığı. (1999). Sayısal veriler. Ankara: Milli Eğitim Basımevi

MEB. (2013). İlköğretim kurumları İngilizce dersi öğretim programı. Ankara: Milli Eğitim Bakanlığı Talim ve Terbiye Kurulu Başkanlı̆̆ı.

Merter, F., Şekerci, H. ve Bozkurt, E. (2014). İngilizce öğretenlerinin ikinci sınıf İngilizce dersine ilişkin görüşlerinin değerlendirilmesi. Akademik sosyal Araştırmalar Dergisi, 2, 5, 199-210

Metin, M. (2014). Nicel veri toplama araçları. M. Metin (Editör), Eğitimde bilimsel araştırma yöntemleri, (ss. 161-214), Ankara: Pegem Akademi.

Murcia, M., \& Goodwin, J. (1991). Teaching pronunciation. In M. Celce-Murcia (Ed.), Teaching English as a second or foreign language (2nd ed., pp. 136-153). New York, NY: Newbury House

Od, Ç. (2013). Erken yaşta yabancı dil öğretiminde çizgi filmlerin dinlediğini anlama ve konuşma becerilerine katk1s1. Turkish Studies, 8, 10, 499-508.

Sarıçoban, A. ve Hasdemir, E. (2012). Assessment in English as aforeign language in primary schools in Turkey. Haceetepe Üniversitesi Eğitim Fakültesi Dergisi, 134-145

Sönmez, V. ve Alacapınar, F.G. (2015). Örnekleriyle eğitimde program değerlendirme. Ankara: Anı Yayıncılık.

Scott, W. A. ve Yitreberg, L. H. (2008). Teaching English to children. London: Longman.

Tashakhori, A. ve Teddlie, C. (2003). Handbook of mixed methods in social \& behavioral research. Thousand Oaks: Sage.

Turgut, M.F. ve Baykul, Y. (2013). Eğitimde ölçme ve değerlendirme (5. Baskı). Ankara: Pegem Akademi Yayıncilik.

Wright, A. (1990). Pictures for language learning. Cambridge: Cambridge University.

Yıldırım, A. ve Şimşek, H. (2013). Sosyal bilimlerde nitel araştırma yöntemleri (9. Baskı). Ankara: Seçkin Yayınc1lik.

Yıldıran, C.. ve Tanrıseven, I. (2015). İngilizce öğretmenlerinin ilkokul 2. sınıf İngilizce dersi öğretim programı hakkındaki görüşleri. International Journal of Language Academy, 3, 1, 210-223

Yüksel, S. (2003). Türkiye'de program geliştirme çalışmaları ve sorunları. Milli Eğitim Dergisi, 159.

\section{Citation Information}

Kurt, A. (2017). 4. Sınıf İngilizce Dersi Öğretim Programının Bağlam, Girdi, Süreç, Ürün Modeline Göre

Değerlendirilmesi. Dicle Üniversitesi Ziya Gökalp Ë̆itim Fakültesi Dergisi, 30, 508-524. 